\title{
LA ORGANIZACIÓN DEL SANTO OFICIO Y EL NOMBRAMIENTO DE INQUISIDOR GENERAL POR EL ARCHIDUQUE CARLOS (1709-1715)
}

por

JosÉ SOLÍS

Universidad de Zaragoza

RESUMEN: En este artículo se estudia el mantenimiento de la estructura inquisitorial española por el archiduque Carlos y las circunstancias de la designación, por este, de inquisidor general en los territorios de la Monarquía bajo su obediencia. En dichos territorios el archiduque conservó, junto al resto de las instituciones, la administración propia del Santo Oficio. El problema especial lo planteó la necesidad, característica del gobierno de la Inquisición, de contar con la intervención del inquisidor general en el nombramiento de diferentes empleos pertenecientes a la misma. En consecuencia, el archiduque demandó y obtuvo del papa el reconocimiento de su prerrogativa de realizar, como Rey Católico, el nombramiento de inquisidor general.

Palabras clave: Siglo XVIII. Guerra de Sucesión española. Archiduque Carlos. Inquisición española. Inquisidor general.

ABSTRACT: This article analyses the structure of the Spanish Inquisition and the way in which it was maintained by Archduke Carlos. It also deals with the circumstances surrounding the archduke's appointment of the grand inquisitor in the territories of the Monarchy under bis rule. In these territories the archduke preserved, together with the rest of the institutions, the administration of the Holy Office itself. A special problem arose from the fact that, as with everything related to the government of the Inquisition, the intervention of the grand inquisitor was needed when designating people to the various different posts within this administration. Eventually, the archduke induced the Pope to recognise his prerogative, as Catbolic King, to appoint the grand inquisitor.

KEY WORDS: Eighteenth Century. Spanish War of Succession. Archduke Carlos. Spanish Inquisition. Grand Inquisitor. 


\section{INTRODUCCIÓN}

La organización de la administración de justicia en los territorios bajo autoridad del archiduque Carlos, durante la guerra de sucesión española, hacía preciso el mantenimiento o la nueva formación de los correspondientes tribunales en materia de fe. La conservación de la religión y, en consecuencia, la necesidad de la función inquisitorial, eran consustanciales a la proclamación y defensa de la continuidad dinástica en la persona del archiduque. De hecho, sus partidarios - y, por supuesto, los dos principales historiadores de su reinado en España, Narciso Feliu ${ }^{1}$ y Francisco de Castellví ${ }^{2}$ - loaron la devoción especial, clásica, de este monarca al Santísimo Sacramento y denunciaron también atentados a la Iglesia y profanaciones cometidas en las poblaciones fieles al rey Carlos por las tropas borbónicas.

Sin embargo, fueron los defensores de Felipe $\mathrm{V}$ quienes utilizaron de manera casi sistemática la propaganda religiosa, alcanzando, por lo que parece, resultados efectivos. No en vano era evidente la presencia de «herejes» entre los componentes del ejército aliado. También fue conocido y muy divulgado el traumático saqueo de las iglesias del Puerto de Santa María realizado en nombre del archiduque en 1702. De sus consecuencias fatales para la causa austriaca, que silencia Feliu en los Anales, se hace eco años más tarde Francisco de Castellví, quien encuentra en ellos respuesta a la constancia de Castilla en aborrecer a los aliados. Es también Castellví el que se lamenta amargamente de «un engaño que fue muy perjudicial» divulgado en Tarazona y en Calahorra, en 1706, según el cual se afirmaba, y así lo había atestiguado un clérigo enviado para comprobarlo por el obispo de Tarazona, que los ingleses estaban haciendo uso para su culto del templo dedicado en Zaragoza a la Virgen del Pilar ${ }^{3}$.

A todo ello se unía la realidad, esta sí cierta, del abandono de sus sedes por los tribunales inquisitoriales de los territorios de la corona de Aragón una vez que estos reinos y principado pasaron a la obediencia del archiduque. Castellví reseña en cuanto a Cataluña: "Se ausentaron los inquisidores y todos los obispos a la excepción del arzobispo de Tarragona y obispo de Solsona. El permitirlo se consideró notable error, porque estos actos confirmaron a los demás naturales de las provincias de España en que se subvertía la Religión, aprehensión que se imprimió y quedó indeleble en la mente del pueblo» ${ }^{4}$. En general, todo el aparato inquisitorial, como se expone a continuación, se pronunció en favor del rey Felipe V.

\footnotetext{
1 Feliu de la Peña, Narciso: Anales de Cataluña, Barcelona, 1709 (hay reedición de 1999).

2 CaStellví, Francisco de: Narraciones históricas desde el año 1700 basta el año 1725. Las conocidas Narraciones de Castellví no han sido publicadas hasta fecha reciente, en 4 vols., por la Fundación Elías de Tejada, Madrid, 1997, 1998, 1999 y 2002.

3 CASTEllví: Narraciones, I, p. 368 y II, p. 133.

${ }^{4}$ Castellví: Narraciones, I, pp. 556-557.
} 


\section{LA ORGANIZACIÓN TERRITORIAL DEL SANTO OFICIO Y EL GOBIERNO DE CARLOS DE AUSTRIA}

En 1705 el tribunal de la Inquisición de Barcelona se declaró de manera inequívoca por el rey Felipe, al igual que harían también más adelante los tribunales inquisitoriales de otros distritos, como los de Valencia y de Zaragoza, en el momento de pasar estas ciudades a la obediencia austriaca.

En Barcelona, los inquisidores don Pedro de Soto y don Antonio Ribero salieron de la ciudad al mismo tiempo que lo hizo el entonces virrey Francisco de Velasco, con quien embarcaron el 15 de octubre de 1705 «antes de amanecer» 6 . La salida de Barcelona de los inquisidores se realizó a pesar de que en las capitulaciones de la plaza otorgadas el 9 de octubre de dicho año 1705 se había concedido la petición, formulada de manera expresa en el capítulo cuarenta y ocho de las mismas, de mantener el tribunal de la Inquisición y a sus componentes.

«48. Que se permita y continúe el tribunal de la Santa Inquisición como se ha hecho hasta ahora, con las mismas prerrogativas, jurisdicción y privilegios, dejando a la elección de los inquisidores y demás oficiales actuales que componen aquel tribunal, que en caso de no querer permanecer en esta ciudad puedan salirse de ella, gozando de las mismas inmunidades que los demás, así respecto de sus personas como de sus bienes, en la conformidad que está expresado en los capítulos antecedentes en lo tocante a los ministros de la Real Audiencia. = Concedido» 7 .

De todos modos, los inquisidores de este tribunal tomaron la decisión de abandonar la ciudad. Lo hicieron adhiriéndose así de manera notoria al partido de Felipe V. Dejaron en Barcelona los papeles de la Inquisición al cuidado de uno de los secretarios; se llevaron consigo, eso sí, el retrato del rey Felipe que había en el cuarto del secreto ${ }^{8}$. En 1706 los citados inquisidores del tribunal de la Inquisición de Barcelona fueron compensados por Felipe V con «empleos correspondientes a su grado»?.

En Valencia, a comienzos de 1706, «a 2 de enero", se ausentaron los inquisidores y el secretario del tribunal de la Inquisición «siguiendo el partido del rey Felipe», acompañando al arzobispo y seguidos de muchos de los miembros de la audiencia «y de mayor número de la primera jerarquía de la nobleza». Los inquisidores eran don Juan de Latorre y don José Tarancón; el secretario que

5 FELIU: Anales, III, p. 542.

${ }^{6}$ Castellví: Narraciones, I, p. 556.

7 Cfr. Castellví: Narraciones, I, p. 666.

${ }^{8}$ Cfr. Archivo Histórico Nacional, Inquisición, leg. 2.157, «Memoria de las alhajas y trastos del santo tribunal de la inquisición de Barcelona que se hallan así en el secreto como fuera de él (Barcelona, 14 noviembre 1715)». Publicada por Voltes Bou, Pedro: «Documentos para la historia del Tribunal de la Inquisición de Barcelona durante la Guerra de Sucesión», en Analecta Sacra Tarraconensia, 26 (1953), pp. 266-268.

9 CASTEllví: Narraciones, II, p. 231. 
partió con ellos fue don Carlos Albornoz ${ }^{10}$. Y sin embargo, según el Diario de José Vicente Ortí11, parece que el 30 de septiembre de 1706 , cuando el rey Carlos hizo su entrada de incógnito en Valencia, acudieron a recibirlo, entre otros representantes del reino y de la ciudad, el citado don Juan de Latorre y don Isidro de Valmaseda, en nombre de la Inquisición. Es este mismo inquisidor Valmaseda quien actuará desde los inicios de la Nueva Planta contra el numeroso clero valenciano disidente ${ }^{12}$.

En Zaragoza, el abandono de la capital del reino de Aragón por los inquisidores se habría producido, según Castellví, de un modo similar, a mediados de julio de 1706; salieron de la ciudad «después de aclamado el rey Carlos», siguiendo el partido del rey Felipe, junto al arzobispo y al obispo auxiliar ${ }^{13}$.

Por lo que se refiere a Cataluña, el secretario que permaneció en Barcelona, don Manuel Viñals de Latorre, lo hizo — como se encargaría él mismo de justificar- acatando la orden del «año cinco» que «le dejó en forma (...) el señor inquisidor don Pedro de Soto» y con la finalidad «de cuidar de la guarda de los papeles del secreto, de la hazienda y demás dependencias» del Santo Tribunal ${ }^{14}$. La disposición había sido tomada con la intención de trasladar más adelante el tribunal de la Inquisición de Barcelona a Gerona o a Tortosa, siguiendo el ejemplo de lo realizado con «los papeles del secreto» en "el año de. 1697, cuando, entregada Barcelona, se pasó a Tortosa el tribunal, que éste lo dejó todo fiado al cuidado del Secretario (...) con orden de que, en caso de querer poner quartel los enemigos en la Inquisición (...), los pasasen con las alhajas al archivo de la catedral pidiendo al cabildo que lo permitiese». En 1706 los inquisidores de Barcelona habían resuelto lo mismo, previniendo al vicario general (el más que voluble en sus fidelidades doctor José Romaguera, cuya «insensibilidad» era «muy igual a su habilidad», según queja del obispo, el luego cardenal Sala ${ }^{15}$ ) y al cabildo para que ayudasen al secretario y al comisario que quedaban al cuidado de la documentación y de las pertenencias del Santo Oficio. En la ocasión oportuna se intentaría trasladar esta documentación, que quedaba en la ciudad, al lugar donde se decidiese establecer el tribunal de distrito de Barcelona ${ }^{16}$.

10 CASTELLVí: Narraciones, II, pp. 37 y 233.

11 «Diario de lo sucedido en la ciudad de Valencia desde el día 3 del mes de octubre del año 1700 , hasta el día $1^{\circ}$ del mes de septiembre del año 1715», por José Vicente Ortí y Mayor (ms. 460 de la Biblioteca Universitaria de Valencia). Cfr. ALDANA FERNÁNDEZ, Salvador: «Valencia y el Archiduque Carlos de Austria», en Boletín de la Sociedad Castellonense de Cultura, 34 (1956), pp. 32 y 48.

12 GIMÉNEZ LÓPEZ, Enrique: «El peligro austracista en tierras valencianas tras la Guerra de Sucesión", en Gobernar con una misma Ley. Sobre la Nueva Planta borbónica en Valencia, Alicante, 1999, p. 82.

13 CASTEllví: Narraciones, II, p. 241.

14 A.H.N., Inquisición, leg. 2.157, «Informe de fecha 27 de septiembre de 1714 de Manuel Viñals de la Torre al Consejo de la Santa General Inquisición, sobre el estado de la hacienda y demás dependencias del santo tribunal de Barcelona». En VolTES: «Documentos», pp. 261-263.

15 Cfr. GIRBAL, Enrique Claudio: Biografía del cardenal gerundense D. Fr. Benito de Sala y de Caramany, Gerona, 1886, p. 21 , nota 3.

16 A.H.N., Inquisición, leg. 4.650, «Informe de 25 de febrero de 1706 de los inquisidores de Barcelona sobre su salida de la ciudad». En VolTEs: «Documentos», pp. 258-260.

Hispania, LXV/2, núm. 220 (2005) 515-542 
Finalmente, los papeles permanecieron durante todo el dominio austriaco en la capital del Principado (al cuidado del mencionado secretario Manuel Viñals), sin que llegara a efectuarse la solución propuesta en diciembre de 1705 por el entonces inquisidor general don Vidal Marín para constituir el tribunal de la Inquisición de Barcelona en Barbastro «o en otra parte acomodada que fuere Vuestra Magestad servido; para que, hallándose tan cercano al Principado, pueda usar de su Santo Ministerio admitiendo a los que viniesen a reducirse a nuestra Santa Fe», estando como estaba "poseído tiranamente el Principado de herejes y sublevados» ${ }^{17}$.

La concurrencia de «herejes» no supuso amenaza alguna para la fe católica en la ciudad. Feliu incluye expresamente en los Anales la aclaración de que los presos en las cárceles inquisitoriales, la mayoría de ellos eclesiásticos, lo estaban por razón de estado, y nunca por causa de religión ${ }^{18}$. Castellví, en medio del relato de los disturbios que ocurrieron en Barcelona el día 14 de octubre de 1705, cuando la población desarmó a la guarnición borbónica que acababa de capitular, destaca el siguiente hecho: «Pasaron después a abrir las cárceles, la pública, la del obispo y la torre de las Pulgas. Sólo respetaron el sagrado del tribunal de la Santa Inquisición, que ninguno de aquella confusa plebe entró en aquel venerado lugar» ${ }^{19}$. Concuerda con el testimonio de Feliu, en relación con unos acontecimientos que este último presenció: «A este tiempo vna muger llamada Geronyma Peyrò, deseando librar los Presos, mandò à su hijo Antonio Peyrò subir al Campanario de la Iglesia de Santa Marta, vezina à la Torre à tocàr a rebato; y despues tocò la Campana de la Iglesia de Santa Maria del Mar, las quales pusieron en Arma á toda la Ciudad; y tocando despues todas las Campanas, infundieron inexplicable temor â toda la Guarnicion. La primera accion fuè, sacarnos de la Torre, y llevarnos á Casa de la Ciudad: Luego sacaron los Presos de las Carceles Reales, y del Obispo; y despues haziendose dueños de la Atarazana, sacaron los Presos de la Torre de las Pulgas; y fuè tal la atencion de los Barceloneses al Santo Tribunal de la Inquisicion, que nadie se atreviò â intentar sacar los Presos de sus Carceles» ${ }^{20}$.

La única novedad en Barcelona con respecto al santo ministerio podía afectar a su organización, y provenía tan sólo del celo del rey Carlos por mantener los tribunales inquisitoriales en el territorio de su soberanía. Precisamente una de las primeras cuestiones que debió consultar la Junta de Estado de 1705 fue la adopción de medidas para la defensa de la religión, ante la ausencia de los inquisidores de Cataluña ${ }^{21}$. De este modo, el rey Carlos realizaría una serie de nombramien-

17 A.H.N., Inquisición, leg. 4.650, «Dictamen de 16 de diciembre de 1705 del Inquisidor General y el Consejo sobre la formación fuera de Barcelona del tribunal de la Inquisición de distrito». En VOLTES: «Documentos», pp. 251-252.

18 FELIU: Anales, III, p. 614.

19 CASTEllví: Narraciones, I, p. 551.

20 FeliU: Anales, III, p. 541.

21 Vid. al respecto Solís, José: «Política catalana de Carlos de Austria: la Real Junta de Estado y la Junta de Medios de 1705», en Revista de Estudios Políticos, 118 (2002), p. 247. 
tos para que en su momento pudiese actuar el correspondiente tribunal. Mediante despacho fechado en Vilafranca del Penedès el 28 de junio de $1706^{22}$, el rey Carlos designó dos inquisidores y un fiscal para el citado tribunal de Barcelona $^{23}$ : Miguel Calderó (el antiguo regente de la audiencia ${ }^{24}$ ) y José Bosch, canónigo de Vic, como inquisidores; Agustín Ramoneda (un beneficiado de la Seo de Barcelona ${ }^{25}$ ) como fiscal. En el decreto de nombramiento se les prohibía firmemente entrometerse en «materias del secreto del Santo Oficio, ni concernientes al ministerio de la jurisdicción apostólica, (...) antes de obtener los despachos apostólicos» ${ }^{26}$.

Seis meses después de estos nombramientos de inquisidores y fiscal, el rey Carlos designaba a dos secretarios para el mismo tribunal de la Inquisición de Cataluña, siendo nombrados los doctores Pedro Pedrosa y Félix Vilaroger, por decreto fechado en Valencia el 15 de diciembre de 1706:

«Considerando la falta de Secretarios para la asistencia del Tribunal del Sto. Oficio de la Inquisición de ese mi principado de Cataluña y de los Sujetos para Inquisidores nombrados con otra mía que mandé despachar en mi villa de Villafranca del Panadés del dicho Principado en 28 de junio pasado, he resuelto elegir y nombrar como elijo y nombro para Secretarios del Secreto del citado Tribunal de la Sta. Inquisición de Cataluña a vosotros, los Doctores Pedro Pedrosa y Félix Vilaroger, Presbíteros, teniendo entera satisfacción de la integridad y aplicación con que atenderéis y obraréis en este Oficio, con todo lo cual, sus anexos, conexos, dependientes e incidentes os doy y atribuyo desde ahora amplio poder y autoridad, concediéndoos que gocéis de los honores, prerrogativas, preeminencias [y] gajes tocantes a los Secretarios que han sido del Tribunal del Sto. Oficio, a cuyo fin mando al receptor, o a quien hiciere este oficio a la Inquisición, os de y pague cada un año por sus tercias según lo acostumbrado, y que podáis recurrir a Su Santidad, que de presente es el único recurso para obtener los despachos que necesitáis por el ejercicio de la Jurisdicción Apostólica en los casos que tocan al conocimiento del Sto. Oficio, y si para todo o cualquier parte de lo referido hubiéreis menester favor y ayuda, acudiréis al Lugarteniente y Capitán General de ese mi Principado por lo que toca a mi jurisdicción Real, a quien encargaremos y mandaremos, como por la parte, ahora por entonces, encargo y mando, os lo den tan cumplido como lo pidiéradeis y necesitaseis. Dado en mi ciudad de Valencia a quince días del mes de diciembre de mil setecientos y seis años. Yo el Rey. D. Ramón de Vilana Perlas Secret. [1 $1^{a}$ columna $]$ Vt. Aguirre Reg. Vt. Be-

22 BlázqueZ Miguel, Juan: La Inquisición en Cataluña. El tribunal del Santo Oficio de Barcelona 1487-1820, Toledo, 1990, p. 132.

23 MartíneZ MILlÁN, José: «La Inquisición en Cataluña durante el siglo XVIII. ¿Una institución en crisis?», en Pedralbes. Revista d'Història Moderna, 4 (1984), p. 73.

24 Cfr. CASTEllví: Narraciones, I, p. 424 y II, p. 239.

25 VOLTES: «Documentos», p. 254.

26 BLÁZQUEZ: La Inquisición en Cataluña, p. 132 (la cita en A.H.N., Inquisición, leg. 2.157).

Hispania, LXV/2, núm. 220 (2005) 515-542 
rardo. Vt. Eman. Mercader. [2 $2^{\text {a }}$ columna] Vt. Estanga Regens. Vt. Comes de Elda. Vt. Marchio de Coscojuela»27.

En cuanto al receptor del tribunal a que se hace referencia en este decreto de 15 de diciembre de 1706, quien hacía «este oficio a la Inquisición» era Jaime Circuns. Recibiría un despacho en forma para tal cometido el 11 de enero de 1710 , «faltando la regular providencia (...) en el interin (...) de manera que (...) pueda dar recibos, cartas de pago u otros instrumentos que para resguardo de los interesados considerare necesarios (...) con lo cual (...) pueda el santo tribunal, luego de formado, atender a los gastos que en el ejercicio y uso de él son indispensables» ${ }^{28}$.

En lo que atañe a la Inquisición de Aragón, consta la existencia de inquisidores en enero de 1707; aunque con dudas por su parte acerca de la estructura en la que se integran sus actuaciones ${ }^{29}$. Con fecha de 4 de noviembre de 1706 y de 25 de febrero de 1707, aparecen inscritos en la cofradía de San Pedro Mártir, que congregaba a los ministros del Santo Oficio, dos calificadores del tribunal de distrito de Zaragoza ${ }^{30}$. Estos nuevos calificadores fueron, respectivamente, fray Pedro de San Agustín y fray Laureano de Santo Tomás, agustinos descalzos vinculados probablemente al prior del convento de agustinos de $\mathrm{Za}$ ragoza fray Diego Panzano, calificador del Santo Oficio desde el año 1696 y miembro de la Junta Eclesiástica de Aragón, nombrado para esa Junta por el rey Carlos el 23 de julio de $1706^{31}$.

Todos los nombramientos inquisitoriales realizados por el rey Carlos se habrían tramitado de forma por completo irregular. Así lo exponía, por si acaso, el secretario del tribunal de la Inquisición de Barcelona, el antes citado Manuel Viñals, respecto de los nombramientos efectuados en esa Inquisición sin la asistencia del inquisidor general y del Consejo del Santo Oficio:

«(...) habiendo tenido extrajudicial noticia de que V.M. había sido servido firmar despachos con nombres de inquisidores y fiscal (...) y con los cuales manda V.M. puedan pasar a residir en el Real Palacio donde moran los inquisidores, cobrar sus respectivos salarios, y que para ejercer las jurisdicciones que a aquéllos

27 Archivo de la Corona de Aragón, Cancillería, Cartas Reales, Archiduque Carlos de Austria, caja 4, carpeta e, documento núm. 9, «Decreto del rey Carlos III de nombramiento de secretarios del tribunal de la Inquisición de Barcelona. Valencia, 15 diciembre 1706».

28 A.H.N., Inquisición, legajo 4.645, impreso, «Despacho de nombramiento de receptor del tribunal de la inquisición de Barcelona. Llagostera, 11 enero 1710». Publicado por Voltes: «Documentos», pp. 260-261.

29 A.H.N., Estado, libro 993, fol. 185r, «Consulta de la Junta Política, de 21 de enero de 1707, sobre diversos asuntos referentes al Reino de Aragón».

30 Pasamar LÁzaro, José Enrique: La Cofradía de San Pedro Mártir de Verona en el distrito inquisitorial de Aragón, Zaragoza, 1997, pp. 105 y 107.

31 Solís, José: «Las Juntas de Secuestros y Confiscaciones del Archiduque Carlos en Cataluña, Aragón y Valencia», en Anuario de Historia del Derecho Español, 69 (1999), pp. 433, 434, 448 y 455.

Hispania, LXV/2, núm. 220 (2005) 515-542 
incumbe acudan a la Santa Sede, serle indispensable representar a V.M. que lo que se ha observado inconcusamente en la carrera del Santo Oficio es que este se gobierna por un Inquisidor General junto con el Consejo Supremo de la Inquisición, de forma que todas las dependencias (...) no se terminan sin pasar por el (...) Inquisidor General y Consejo»32.

\section{EL INQUISIDOR GENERAL Y EL CONSEJO DE LA SUPREMA EN LOS PRIMEROS AÑOS DEL REINADO DE FELIPE V}

En principio, los nombramientos referentes a la Inquisición deben ser realizados con acuerdo del inquisidor general y del Consejo de la Suprema, siendo aquél quien, por lo demás, confiere la jurisdicción apostólica necesaria para el ejercicio del empleo. En la Inquisición se manifestó, desde el inicio del reinado de Felipe V, una disputa por el ejercicio de la máxima autoridad entre quien entonces ejercía el cargo de inquisidor general (don Baltasar de Mendoza ${ }^{33}$, conocido partidario austriaco) y los miembros del Consejo, obedientes al rey Felipe como al menos hacía formalmente el resto del aparato inquisitorial. Por lo que parece, hasta el nombramiento de don Vidal Marín como inquisidor general, en 1705, la Inquisición no adoptó una posición inequívoca en favor de la nueva dinastía ${ }^{34}$.

El motivo primero de oposición del Consejo hacia el criterio del inquisidor estuvo ocasionado por el proceso contra el padre maestro don fray Froilán Díaz (ya entonces destituido de su cargo de confesor real) que incoó el inquisidor general Mendoza, al poco tiempo de su nombramiento, en ejercicio de sus funciones «contra la heregía y para la defensa de la fe cristiana de toda apostasía y maldad» ${ }^{35}$. Los consejeros de la Suprema, a diferencia del inquisidor, votaron la suspensión del caso, estimando que no existía materia de fe. Aun con todo Mendoza firmó con fecha 8 de julio de 1700 un decreto ordenando la prisión del padre Díaz, al cual se opuso igualmente el Consejo. La reacción a ello del

32 Cit. por VolTES: «Documentos», pp. 254-255.

33 Baltasar de Mendoza y Sandoval (nombrado obispo de Segovia el 5 de octubre de 1699) obtuvo también de Inocencio XII el breve de inquisidor general en 31 de octubre del mismo año 1699, sustituyendo en este cargo al cardenal don Alonso de Aguilar Fernández de Córdoba (quien nunca tomó posesión, puesto que falleció el mismo día en que llegó el breve con su nombramiento). Cfr. BARrio Gozalo, Maximiliano: «La oposición a los Borbones españoles al comenzar el siglo XVIII y el exilio de eclesiásticos. Don Baltasar de Mendoza y Sandoval, Obispo de Segovia e Inquisidor General», en Anthologica Annua, 43 (1996), pp. 590-591.

34 LÓPEZ VeLA, Roberto: «La Inquisición a la llegada de Felipe V. El Proyecto de cambio en su organización y bases sociales», en Revista Internacional de Sociología, 46 (1988), p. 74.

35 BARRIO GOZALO, Maximiliano: «El nombramiento del Inquisidor General. Un conflicto jurisdiccional a principios del siglo XVIII», en Perfiles jurídicos de la Inquisición española, José Antonio Escudero (edit.), Madrid, 1989, p. 544 (la cita: Archivio Vaticano, Sec. Brev., vol. 2.020, fols. 223225, «Breve pro Balthasare Epo. Segobien. Deputatio in inquisitorem Generalem in regnis Hispaniarum. Roma 31 october $1699 »)$.

Hispania, LXV/2, núm. 220 (2005) 515-542 
inquisidor fue ordenar ese mismo día el confinamiento inmediato de tres de los consejeros que se habían enfrentado a su dictamen ${ }^{36}$ (los consejeros don Antonio Zambrana, don Juan Arzeamendi y don Juan Miguélez), cuya jubilación conseguiría poco después. En su lugar entraron en el Consejo don Alonso de Navia, don Juan José de Tejada y don Domingo Pernas, por nombramientos de fechas 9, 13 y 20 de septiembre de 1700 respectivamente; el 26 de mayo del mismo año 1700 había sido nombrado consejero el padre maestro don fray Nicolás de Torres Palmosa, sucesor del padre Díaz en el cargo de confesor real ${ }^{37}$.

El rey Felipe V, en los comienzos de su ingreso en la Monarquía, por orden fechada al parecer el 14 de febrero de 1701, reintegraba al inquisidor general a su obispado de Segovia, obligándolo a abandonar la corte y cesándolo en sus funciones de inquisidor; don Baltasar de Mendoza era destituido así igualmente de la Junta de Regencia a la cual pertenecía. Además, el decreto del rey Felipe disponía que a partir de entonces el Consejo de la Inquisición debía proceder con la facultad que tenía de la sede apostólica en los supuestos en los cuales no había inquisidor general. El enfrentamiento entre el inquisidor general y el Consejo no finalizó con la suspensión del inquisidor general en sus funciones. Este continuó intentando hacer valer su superioridad en la Inquisición. Por una parte, y previa autorización de la Santa Sede comunicada con fecha de 5 de agosto de 1702, prosiguiendo con la causa contra don Froilán Díaz incoada por el fiscal de la Suprema don Juan Fernando de Frías; por otra parte, denunciando la continuación en su puesto del consejero don Juan José de Tejada, quien había renunciado ante el inquisidor sin que esto fuera admitido por el monarca ${ }^{38}$.

Este asunto fue el que tuvo quizá una mayor trascendencia institucional, al afectar plenamente a la cuestión del nombramiento de los miembros del Consejo. El consejero de la Inquisición don Juan José de Tejada había renunciado a su plaza el día 15 de julio de 1702, dejación que fue admitida por el inquisidor general. El rey Felipe V, sin embargo, no la aceptó, y mandó al consejero que continuara en el ejercicio de su empleo, lo que el inquisidor general impedía al haber sido admitida la renuncia por su parte. El inquisidor general Mendoza, para defender su pretensión de que estos nombramientos le pertenecían (y por consiguiente había terminado el empleo de Tejada, una vez aceptado por él el cese), presentó al rey, por medio del nuncio Francisco Acquaviva, un papel, titulado Reflexiones, en el que justificaba su competencia exclusiva en los nombramientos para la Suprema, competencia derivada, según él, de las bulas que recibía del sumo pontífice. Por decreto de 24 de noviembre de 1703 el rey Felipe V remitió estas Reflexiones al Consejo de la Inquisición, que en su respuesta "comprobó y demostró que los nombramientos de todos los empleados en la Inquisición co-

36 LEA, Henry Charles: Historia de la Inquisición española (Nueva York, 1906-1907), ed. de la Fundación Universitaria Española, vol. II, Madrid, 1983, p. 29.

37 Cfr. Gómez Rivero, Ricardo: «Consejeros de la Suprema de Felipe V», en Revista de la Inquisición, 4 (1995), pp. 146-147.

38 BARRIO GOZALO: «El nombramiento del Inquisidor General», pp. 547, 550 y 551.

Hispania, LXV/2, núm. 220 (2005) 515-542 
rresponden y pertenecen al rey, por soberano y por fundador de la Inquisición, y que las bulas apostólicas sólo confieren la jurisdicción y facultad de deputar y comunicarla a los nombrados por S. M.» ${ }^{39}$.

Sometidas las cuestiones de competencia a consulta de sus Consejos de Inquisición y de Castilla, Felipe V decretó, conforme a las mismas, con fecha 3 de noviembre de 1704, la reposición en sus puestos de los tres ministros de la Suprema jubilados por el inquisidor, así como, a consulta del Consejo de la Inquisición de 17 de noviembre de 1704, la restitución del padre Díaz en su plaza en el Consejo ${ }^{40}$, consulta esta última que firman, por cierto, los consejeros Navia y Pernas, dos de los nombrados por Mendoza. Cinco días más tarde se comunicaba la resolución al inquisidor ${ }^{41}$. Por decreto de 25 de abril de 1705 Felipe V ordenó la destitución definitiva de don Baltasar de Mendoza en su oficio de inquisidor general ${ }^{42}$.

Retirado a su diócesis, el obispo Mendoza se vio aún perjudicado al año siguiente, en 1706, por los disturbios que se produjeron durante el levantamiento de la ciudad de Segovia contra el dominio del rey Carlos, en el curso de los cuales, el día 25 de julio ${ }^{43}$, se asaltó el palacio episcopal acusándose al obispo de ser partidario de los austriacos. El obispo Baltasar de Mendoza tuvo que huir de la ciudad y, en su huida, fue preso y culpado de querer unirse al campo del archiduque, lo que, en efecto, parece que pretendía hacer. El ya citado historiador Francisco de Castellví recoge del siguiente modo en sus Narraciones bistóricas el destierro posterior de Baltasar de Mendoza:

«Al pasar el ejército aliado a Guadalajara se conmovió el pueblo de Segovia, aclamó al Rey Felipe, sitió la guarnición portuguesa del Alcázar que se rindió a pacto de dejar el paso libre al ejército, el bajo pueblo insultó con piedras el palacio del Obispo por que le consideraban austriaco, en aquel conflicto asistió al Obispo D. Alonso Peralta, y por una puerta falsa de un jardín le condujo a los jesuitas, rompieron los vidrios de su palacio y cometió algún desorden la manco-

39 La cita entrecomillada y la exposición corresponden a un «Informe reservado elaborado a petición del ministro de estado Ricardo Wall por Pedro Cantos y Pedro Ric, consejeros de Castilla y de la Suprema, en el que exponen ciertos aspectos referentes al Consejo de la Inquisición, sobre el establecimiento de la Inquisición y erección de su Consejo y Tribunales» (A.H.N., Estado, leg. 6.380,1). Este informe sigue en buena medida la representación del Consejo de la Inquisición al rey Felipe V de 18 de julio de 1703 «fundando el voto decisivo de sus ministros» y las "consultas y papeles [del Consejo de la Inquisición y del Consejo de Castilla] que motivaron la causa del maestro Froilán». Está publicado por Gómez Rivero como apéndice II en «Consejeros de la Suprema de Felipe V».

40 LEA: Historia de la Inquisición española, vol. II, pp. 32-33.

41 GARCía BARriuso, Patrocinio: «La actuación del Inquisidor Mendoza y Sandoval», en Historia de la Inquisición en España y América, dirigida por Joaquín Pérez Villanueva y Bartolomé Escandell Bonet, vol. I, Madrid, 1984, p. 1113.

42 BARRIO GOZALO: «El nombramiento del Inquisidor General», p. 554.

43 LAÍNEZ, Marcelo: «Apuntes históricos de Segovia», en Estudios Segovianos, 16 (1964), pp. 148-149.

Hispania, LXV/2, núm. 220 (2005) 515-542 
munada plebe en el palacio. El Obispo, por librarse del peligro, salió de Segovia, marchó a Madrid y a Guadalajara, fue reconocido de un arriero, muy cómodo este dió aviso a una partida que le prendió por que se juzgó se pasaba al partido de los austriacos; fue desterrado de España y conducido a Aviñón; el que acusó al Obispo de que se pasara perdió en tres años sus caudales, atribuyó su desgracia a la ocasión, vestido de peregrino pasó a Aviñón, pidió perdón al Obispo, que le dio la bendición y le dijo: Dios te perdone, y le dio limosna para volverse a su tierra; el Obispo, después de algunos años volvió a su obispado, pero no quiso entrar más en Segovia y pasó a vivir en el último lugar de su diócesis» ${ }^{44}$.

A partir del nombramiento de un nuevo inquisidor general, el obispo de Ceuta don Vidal Marín, quien accede al cargo el 28 de abril de $1705^{45}$, la Inquisición actuó de forma inequívoca en defensa del mantenimiento de la monarquía del rey Felipe. El Consejo de la Inquisición ordenó a los tribunales de distrito que exigiesen a todos sus oficiales y empleados formal fidelidad a Felipe V. El modo más expeditivo que utilizó el Santo Oficio en su propósito de garantizar el respeto a la lealtad jurada, fue la publicación del edicto de 9 de octubre de 1706, impreso y fijado en las iglesias para su conocimiento al modo tradicional ${ }^{46}$. Con este se prescribía la obligación de los penitentes de «denunciar y delatar» a aquellos confesores que «en el acto de la confesión sacramental» justificasen la licitud de faltar al juramento de fidelidad prestado al rey Felipe. El propio Clemente XI había confirmado la obligación «en justicia y conciencia» de observar dicho juramento.

«Nos los Inquisidores apostólicos contra la herética pravedad y apostasía: en esta corte de su majestad por autoridad apostólica. Habiendo llegado a nuestra noticia que, sin embargo de las justísimas providencias con que la santidad de nuestro muy Santo Padre Clemente undécimo ha ocurrido al remedio y castigo de todos los eclesiásticos seculares y regulares que faltasen a la debida obediencia del Rey nuestro señor don Felipe Quinto (que Dios guarde) revalidando y confirmando su santidad por este medio la obligación en justicia y conciencia de la observancia del juramento de fidelidad que todos los vasallos de su majestad le han prestado reconociéndole y llamándole y admitiéndole los tres estados por su legítimo rey y señor natural, hay algunos que maliciosamente persuaden y solicitan a los penitentes en la confesión sacramental la gravísima culpa de inobediencia, infidelidad y rebelión, haciéndoles creer que no les obliga el juramento de fidelidad, sin duda por parecerles más segura y eficaz esta insinuación y sugestión en aquel sagrado lugar y tiempo, de que se valen para eludir y frustrar las penas a que los sujeta la referida disposición de su santidad, con manifiesto abuso del Santo Sacramento de la Penitencia y evidente ruina en lo espiritual y temporal de los

44 CASTEllví: Narraciones, II, p. 150.

45 Martínez Millán, José y SÁNChez Rivilla, Teresa: «El Consejo de Inquisición (14831700)", en Hispania Sacra, 36 (1984), p. 113.

46 EGIDO, Teófanes: «La Inquisición de una España en guerra», en Historia de la Inquisición en España y América, vol. I, pp. 1232-1233. 
catolicísimos y fidelísimos reinos por cuya razón nos toca su conocimiento, y debiendo por la indispensable obligación de nuestro oficio y Santo ministerio atender al resguardo y conservación de la pureza de nuestra sagrada religión en que siempre se han mantenido y preservarla por todos los medios que nos fueren posibles de los comunes daños y riesgos a que le expondría la tolerancia y permisión de tan perniciosa doctrina, hemos resuelto publicar este nuestro edicto declarando como declaramos la obligación que todos los penitentes tienen de denunciar y delatar ante nos a los confesores que en el acto de la confesión sacramental solicitaren, aconsejaren o en alguna manera indujeren a tan execrable delito. Y mandamos que dentro de nueve días de su publicación los delaten y denuncien ante nos o nuestros comisarios, so pena de excomunión mayor en lata sententia ipso facto incurrenda, cuya absolución a nos reservamos, y de otras penas a nuestro arbitrio. En testimonio de lo cual mandamos dar y dimos la presente firmada de nuestros nombres y refrendada del infraescrito secretario. Dada en Madrid a nueve días del mes de octubre de mil setecientos y seis años»47.

Esa exigencia de fidelidad a Felipe $\mathrm{V}$ no podría mantenerse de ese modo a partir del momento en el que el pontífice, en 1709, se comprometió a declarar solemnemente para el rey Carlos idénticos derechos a los del rey Felipe en la sucesión a la Monarquía. A partir de entonces, y con las medidas del todo excesivas adoptadas por el gobierno borbónico, el rey Carlos obtuvo una legitimidad de la que antes carecía, y que además hizo valer siempre que era necesaria la confirmación de sus actuaciones por el santo padre.

El 19 de enero de 1709 se firmaba el tratado entre el papa Clemente XI y el emperador José I. Junto a otras cláusulas, en lo que respecta a la legitimación de la causa del rey Carlos se disponía, por parte del pontífice, la acreditación de un nuncio en la corte de Barcelona con el reconocimiento por Rey Católico del rey Carlos, la admisión de un embajador en Roma en su nombre, conceder a este monarca todas las prerrogativas, indulgencias, cruzada y demás gracias de los Reyes Católicos, la nominación de los beneficios eclesiásticos, la investidura del reino de Nápoles y la proposición para el nombramiento de cardenal de la Corona ${ }^{48}$. La indignación de Felipe $\mathrm{V}$ llegó a uno de sus puntos culminantes. Ratificada la noticia de que el papa se había avenido a reconocer a Carlos de Austria como rey de España, la corte de Madrid adoptó la resolución de expulsar al nuncio. El duque de Uceda, embajador del rey Felipe, ya había formalizado en Roma, el 26 de enero de 1709 , una protesta contra ese reconocimiento ${ }^{49}$.

47 Biblioteca Nacional, ms. 2.569, «Decreto del Santo Tribunal de la Inquisición a petición del rey Felipe Quinto de Borbón, año de 1706», fol. 251r. Reproducido por GALENDE DíAZ, Juan Carlos: «El Santo Oficio durante la Guerra de Sucesión», en Cuadernos de Investigación Histórica, 11 (1987), p. 155

48 CASTELLVí: Narraciones, II, p. 588.

49 OCHOA BRUN, Miguel Ángel: Embajadas rivales. La presencia diplomática de España en Italia durante la Guerra de Sucesión, Madrid, 2002, p. 48, nota 156.

Hispania, LXV/2, núm. 220 (2005) 515-542 
El reconocimiento de Carlos III como rey de España se manifestó en el consistorio de cardenales de 14 de octubre de 1709. El 26 de noviembre de este año 1709 en la iglesia de Santa María del Mar de Barcelona «diò gracias el Rey à Dios Nuestro Señor con el Te Deum por la declaracion, y Breve de su Santidad» $"$.

En el mismo mes de noviembre del año 1709, Felipe V fracasaba en el intento de obtener los breves de Clemente XI confirmando al obispo de Cuenca, don Miguel del Olmo, como nuevo inquisidor general, en sustitución del arzobispo de Zaragoza don Antonio Ibáñez de la Riva Herrera. Riva Herrera había obtenido el breve de inquisidor general el 5 de agosto de $1709^{51}$, en la nominación de Felipe V, tras el fallecimiento el 10 de marzo de 1709 del inquisidor general don Vidal Marín. Ahora, al morir a su vez el cardenal Portocarrero (el 14 de septiembre de 1709), Riva Herrera era presentado, también por el rey Felipe V, para el arzobispado de Toledo. La propuesta de Miguel del Olmo para inquisidor general por parte de Felipe V se produjo con fecha de 16 de noviembre de 1709; a continuación se encargó al auditor de la Rota, don José Molines (excomulgado por Clemente XI desde el 30 de septiembre de ese mismo año $1709^{52}$ ) que suplicara al santo padre la concesión de los correspondientes breves de ejercicio de empleo y de ausencia de residencia de su diócesis del obispo preconizado para inquisidor. El rey advertía al auditor Molines que no solicitara al papa los breves ni comunicara la renuncia del arzobispo de Zaragoza al cargo de inquisidor si sospechaba que podía haber algún inconveniente para la confirmación del nuevo nombramiento:

"Y estaréis advertido de no usar de esta presentación para el cargo de Inquisidor General, ni de la renuncia que hace de él el arzobispo de Zaragoza, a favor de la persona que yo nombre para él, sin tener vos entera seguridad de que en esto no habrá reparo, pues de otra suerte no es mi ánimo procedáis a presentar el despacho al Papa, ni a usar del instrumento de la renuncia del arzobispo de Zaragoza que a este fin se os remite con estos despachos»53.

Felipe V no consiguió los breves del pontífice para que el obispo de Cuenca Miguel del Olmo pudiera ejercer el cargo de inquisidor ${ }^{54}$. En 1711 se ordenaba

so FELIU: Anales, III, p. 652

51 Barruo Gozalo, Maximiliano: «Perfil socio-económico de una élite de poder de la Corona de Aragón, I: Los obispos del reino de Aragón (1556-1834)", en Antbologica Annua, 43 (1996), p. 152 , nota 129.

52 FERNÁNDEZ ALONSO, Justo: «Un período de las relaciones entre Felipe V y la Santa Sede (1709-1717). Sus repercusiones en la nación española de Roma», en Anthologica Annua, 3 (1955), p. 36.

53 GÓMEZ RIVERO, Ricardo: "El nombramiento de Inquisidores Generales en el siglo XVIII", en Perfiles jurídicos, pp. 558-559, nota 6 (la cita entrecomillada corresponde a Archivo General de Simancas, Gracia y Justicia, leg. 629).

54 En efecto, el obispo de Cuenca don Miguel del Olmo, «humilitate doctus, auctoritate pius», no llegó a ser inquisidor general. Este obispo de Cuenca, «fué semejante al oro que pasa siete veces por el crisol antes de que se haga de él una alhaja. Difícilmente se hallará otro prelado que pasase 
a José Molines que devolviera a la corte los despachos que se le habían enviado de «nominación para el empleo de inquisidor general en persona de Don Miguel del Olmo» 55 . Tampoco el inquisidor Antonio Ibáñez de la Riva Herrera recibió antes de su fallecimiento, el 30 de septiembre de 1710, las bulas de su elección para la sede metropolitana de Toledo ${ }^{56}$.

\section{LA DESIGNACIÓN DE INQUISIDOR GENERAL POR EL REY CARLOS: EL OBISPO DE VIC Y EL CARDENAL OBISPO DE BARCELONA}

En estas circunstancias, y vacante como estaba el oficio de inquisidor general a finales del año 1710 por muerte del arzobispo Ibáñez de la Riva Herrera, el rey Carlos podía ejercer su facultad de proponer el nombramiento de nuevo inquisidor, lo cual hizo en la persona de un prelado de prestigio como el obispo de Barcelona, don fray Benito Sala ${ }^{57}$.

La cuestión del nombramiento de inquisidor general por Carlos de Austria había sido tratada ya en las cortes de Cataluña de 1705/1706. En ellas se pidió la elaboración de una normativa específica que regulara el requisito de la naturaleza para el desempeño del empleo de inquisidor general. Concretamente, las cortes pedían la alternancia en el cargo entre naturales de la corona de Castilla

\footnotetext{
por tantos destinos antes de ser colocado en el candelero de la iglesia conquense. Natural de Almadrones en el obispado de Sigüenza, fué instruido y educado en aquella Universidad en el colegio seminario de San Bartolomé y docto en la sagrada teología pasó al colegio mayor de Santa Cruz de Valladolid á cursar cánones y leyes. Añadiendo á su ciencia y gran piedad un noble origen, de caballero de la orden de Santiago fué elevado á inquisidor de Lerena, al arcedianato y una canongía de Compostela, á capellan mayor, canónigo é inquisidor de Toledo y vicario general de su arzobispado, al arcedianato de Alarcon, dignidad de esta santa iglesia, á auditor de la Sacra Rota por la Corona de Castilla, á gran canciller de Milan, á consejero del supremo de Castilla, á gobernador del reino de Galicia y al obispado de Cuenca. Tomó posesion por medio de su apoderado D. Iñigo Fernandez de Velasco, dean de esta santa iglesia, en 7 de Mayo de 1706. Fué uno de los mejores obispos que ha tenido Cuenca. Doctísimo y humilde, celoso y lleno de piedad, fué tan prudente que jamás tomó medidas fuertes con los eclesiásticos. Llamábalos con cualquier pretesto, si los tenia que reprender; y, afable con todos, con ellos apuraba su sabiduría y piedad en lo interior de su cámara. Les ponia delante con tal energía sus deberes y lo que á ellos faltaban y la cuenta severa que Dios les tomaria, que la enmienda era segura, sin dar lugar al público á que los despreciase, ni á sus feligreses á envalentonarse contra sus párrocos. Escribió varios cuadernos de Decisiones Sacrae Rotae, que se hallan inéditos en su colegio: y padre de los pobres, dejó por heredera de sus bienes al Arca de la limosna de esta ciudad. Murió en ella á 28 de Febrero de 1721 y está sepultado en la capilla mayor de la santa Basílica». MuÑOz y SOLIVA, Trifón: Noticias de todos los Ilmos. Señores Obispos que han regido la Diócesis de Cuenca, Cuenca, 1860, pp. 328-329.

s5 GÓMEZ RIVERO: «El nombramiento de Inquisidores Generales», pp. 558-559, nota 6.

56 López GómEZ, María Ángela: «Los Presidentes y Gobernadores del Consejo Supremo de Castilla», en Hidalguía, 210 (1988), p. 691.

57 Albareda, Anselm M. ${ }^{2}$ : «Contribució a la biografia del cardenal dom Benet de Sala O.S.B. abat de Montserrat (la persecuciò de Felip V)», en Analecta Montserratensia, 6 (1925), p. 77.
}

Hispania, LXV/2, núm. 220 (2005) 515-542 
y naturales de la corona de Aragón y, a su vez, la correspondiente alternancia observada para la provisión de los empleos de la corona aragonesa entre aragoneses propiamente dichos, catalanes y valencianos. Los estamentos pedían al rey Carlos, además, que el primer inquisidor general que nombrase fuera natural del principado de Cataluña:

«Que la nominacio de Inquizidor General, la primera vegada se hague de fer en persona natural dels Regnes de Aragò, Principat de Cathalunya, ò de Valencia, y la altre dels demès Regnes dels Dominis de Sa Magestat, y en quant à la primera se observe alternativa. Cap. LXV. Lo Tribunal de la Santa Inquiziciò en lo Principat de Cathalunya, y Regne de Aragò, tinguè principi al gloriòs Sant Ramon de Penyafort, natural de la ciutat de Barcelona, del Sagràt Orde de Predicadors, y Penitencier de la Santedàt de Gregori IX. y de la Magestat del Serenissim Senyor Rey Don Iaume lo Conquistador, lo qual fou lo primer Inquizidor en los Regnes de Espanya, y se continuá lo govern de la suprema potestat del offici de la Santa Inquiziciò en los Regnes de la Corona de Aragò, fins al any 1483. en lo qual la Santedàt de Sixto IV. á peticiò dels Serenissims Senyors Reys Catholichs, Don Fernando, y Dona Isabel, extenguè la suprema potestat del Sant Tribunal, als Regnes de Aragò, Valencia, y Sicilia, y al Principat de Cathalunya, que $\mathrm{ab}$ Indult especial hava concedit al Cardenal Thomàs Torrecremara, del matex Sagràt Orde de Predicadors, en los Regnes de Castella, y Lleò, desdel quel temps en avant, en los Regnes de Espanya, hi haguè un sol Inquizidor General, fins despres de la mort de la dita Serenissima Senyora Reyna Dona Isabel, que la Santedat de Iulio II. constituhi dos Inquizidors Generals, ço es al Cardenal Francisco Ximenez, Arquebisbe de Toledo per los Regnes de Castella, y Lleò, y al Reverent en Christo Pare Ioan Bisbe de Lleyda, per los Regnes de la Corona de Aragò, per mort del qual, la Santedat de Lleo X. creà dos Inquizidors Generals, ço es al Reverent en Christo Pare Lluis Bisbe de Tortosa, per los Regnes de la Corona de Aragò, y a Fr. Ioan Polo de dit Sagràt Orde de Predicadors per lo Regne de Navarra, al qual poch antes havia succehit dit Serenissim Rey Don Fernando, y la matexa Santedát de Lleò X. mort dit Cardenál Francisco Ximenes, encomanó lo govern de la Suprema Inquiziciò de dits Regnes de la Corona de Castella, y Lleò, al Cardenal Adriá Bisbe de Tortosa, qui era Inquizidor Generál en los Regnes de la Corona de Aragò, del qual temps en avant pertenguè la suprema potestát del Sant offici de tots los Regnes, y Provincias de Espanya, á un sol Inquizidor General del Regne de Castella, lo qual ha rezidit en la Vila de Madrit, tenint alli Sou Supremo Tribunal; Y como sie molt posàt en rahò, que los naturals del Regne de Aragò, del Principat de Cathalunya, y de Valencia, gozan tambe del honor de Supremo Inquizidor de tots los Regnes de Espanya: Perçò suplican à V. Magestat los tres Estaments de la present Cort, que ab llur lloaciò, y aprobaciò, li placia estatuhir y ordenar, que de aqui al devant se fasse nominaciò de Persona per al dit empleo de Inquizidor General, quant vacará per mort, renunciaciò, ò altrament, la una vegada de Persona natural verdaderament, y sens dispensaciò nativa dels Regnes de Aragò, del present Principat, ò de Valencia, y la altre vegada dels demès Regnes de $\mathrm{V}$. Magestat; de manera, que esta primera vacant sie nomenada Persona natural, y verdaderament nativa dels dits Regnes de Aragò, del Present Principat de Cathalunya, ò de Valencia, y axi sempre successivament, 
per alternativa, ab altre Persona dels demès Regnes de V. Magestat, disposant, que quant tocará lo torn als dits Regnes de Aragò, Principat de Cathalunya, y Valencia, se observe entre estos la matexa alternativa, y que la primera provissiò se fasse en Persona natural del present Principat, y que lo Inquizidor axi nomenát, dega jurar de guardar la Concordia, y Capitols fets en lo any 1512. confirmats per lo Serenissim Senyor Emperador Don Carlos de inmortal memoria, en las Corts celebradas en la ciutat de Barcelona en lo any 1520. y per lo Papa Leò $\mathrm{X}$. de feliz recordaciò, y axi matex los Capitols concedits per lo dit Cardenal Adriá Bisbe de Tortosa, á ell presentats en dita Cort de Barcelona del any 1520. com, y tambè los Furs, Lleys, y Constitucions dels dits Regnes de Aragò, del present Principat de Cathaluya, y de Valencia. Plau á sa Magestat. Don Ramon de Vilana Perlas. Secret»58.

Ya en 1709 (en la vacante por el fallecimiento del inquisidor don Vidal Marín) el rey Carlos debió de pretender la obtención de la bula de inquisidor general en favor del obispo de Barcelona (prisionero por orden de Felipe V), breve que no pudo obtener estando entonces comprometida esa merced en favor del candidato presentado por el rey Felipe, el arzobispo de Zaragoza don Antonio Ibáñez de la Riva Herrera ${ }^{59}$. La promoción del obispo de Barcelona don fray Benito Sala al cargo de inquisidor general o a alguna otra dignidad, no era únicamente un medio del rey Carlos para mantener a una persona de fidelidad inquebrantable en una alta posición en el seno de la Iglesia, sino, asimismo, uno de los pocos medios mediante los cuales parecía posible liberarlo de su confinamiento en Aviñón.

La Santa Sede, sin embargo, era reacia a conferir el cargo de inquisidor general sin que se hubiera obtenido previamente la libertad del propuesto. De este modo y con la finalidad antes indicada de intentar la liberación y, al mismo tiempo la promoción de fray Benito Sala, el rey Carlos lo designó para cardenal de la Corona, por nombramiento fechado en Barcelona a 8 de abril de $1710^{60}$. La presentación del obispo de Barcelona para el capelo cardenalicio fue recibida con desagrado en las cortes de Madrid y de París. El papa crearía cardenal al obispo Sala en consistorio público de 18 de mayo de 1712 , aunque, en su caso, como en el de otros seis nuevos cardenales entre los declarados en esa ocasión, lo hizo entonces in pectore ${ }^{61}$.

58 Constitucions, capitols, y actes de cort, fetas y otorgats, per la S. C. R. Magestat del Rey Nostre Senyor Don Carlos III, rey de Castella, de Aragò, comte de Barcelona, Ec. en la cort celebrá als cathalans, en la Ciutat de Barcelona, en la Casa de la Deputaciò del General de Cathalunya, en lo any de 1706, Barcelona, 1706, pp. 117-118.

59 ALBAREDA: «Contribució», p. 113.

60 Albareda: «Contribució», p. 116. El padre Anselm Mª Albareda O.S.B., más tarde cardenal, reproduce en la p. 117 de su trabajo citado el documento de esta presentación de parte del rey Carlos, refrendada por el secretario de estado don Juan Antonio Romeo y Anderaz.

61 GIRBAL: Biografía, pp. 25-26: 
Los embajadores del emperador José y del rey Carlos ante la Santa Sede no dejaron de demandar la gracia de inquisidor general para la persona del obispo Sala. Estando en campaña en Castilla, mediante carta de fecha 9 de septiembre de 1710 dirigida a su secretario de estado don Juan Antonio Romeo, el rey Carlos insistía en que su embajador ante el pontífice, el príncipe Avelino, tramitase el nombramiento de inquisidor general: «se repita a Avelino la instancia para las bulas de inquisidor por el obispo de Barcelona, habiéndolo el papa pactado» ${ }^{62}$. El 27 de septiembre de 1710 se hace llegar un nuevo memorial a la Santa Sede «per l'Istitutione» del inquisidor general:

«Persistendo la Maestá Cattolica di Carlo Terzo nella fermissima speranza di veder quanto prima terminato quel gravissimo scandalo che riceve il Mondo Cattolico dal sentire si trova la sua Corte di Barcellona priva per tanti anni della presenza, cura ed assistenza del proprio vescovo e pastore, senza motivo che possa giustificare o render scusabile nel predeto caso la pretensione delli suoi nemici (...) per parte della Maestá medema si prega la innata equitá di Vra. Beat. voglia degnarsi portar nel mentre qualche rimedio a tanto sconcerto concedendo al predeto vescovo di Barcellona (indevitamente mortificato con rigoroso sequestro nella citta d'Avignone, che vol dire nel piu interno della Francia) il Breve d'Inquisitor Grale. sopra tutti li regni, provincie et isole del dominio mediato o inmediato della monarchia di Spagna, che la gia detta Maestá possiede attualmente e che possederá nel futuro» 63 .

Parece que la concesión de dicho empleo fue acordada por el pontífice ${ }^{64}$, aunque no habría llegado a despacharse en ese momento. La razón consistía en la circunstancia del alejamiento de fray Benito Sala de su diócesis, preso en Aviñón, y sin que su liberación pareciera posible. Esto habría llevado al rey Carlos a realizar además otra propuesta para el cargo de inquisidor general en la persona de un prelado también de su confianza, don Manuel Senjust y de Pagès, obispo de Vic, a quien sí se le expidió su correspondiente breve de nombramiento en abril del año $1711^{65}$. Senjust había sido presentado para la sede de Vic por el rey Carlos en $1706^{66}$, y fue preferido por Clemente XI al elegido para la misma por Felipe V, don fray Baltasar Muntaner ${ }^{67}$. Antes, durante el reinado de Felipe V, en el año 1703, Manuel Senjust, siendo canónigo de Tortosa, fue nombrado canciller de la audiencia de Cataluña (y presidente, por lo tanto, de su primera sala) en sustitución de don Miguel Juan de Taverner,

62 CASTEllví: Narraciones, III, p. 187.

63 Biblioteca de Catalunya, ms. 895, «Correspondència rebuda i documentació de Benet Sala, cardenal i bisbe de Barcelona», vol. II, pliego 159.

${ }_{64}$ Cfr. GIRBAL: Biografía, p. 19.

6s MARQuÉs, José María: Las instrucciones de la nunciatura de Barcelona (1710-1713), Roma, 1978, p. 103.

66 FELIU: Anales, III, p. 576.

67 CASTEllví: Narraciones, II, p. 231. 
obispo de Gerona; se trató de una especie de concesión del duque de Anjou al partido o sector constitucionalista del Principado ${ }^{68}$. El rey Carlos le nombró para formar parte de su Junta de Estado de Cataluña en $1705^{69}$.

Si bien se había obtenido el breve de nombramiento de inquisidor general para don Manuel Senjust y de Pagès, la corte de Barcelona demandó en 1712, una vez que se hubo alcanzado el compromiso de los borbónicos para liberar al obispo Sala, la expedición del breve de inquisidor general prometido al ya cardenal in pectore. Dicha solicitud se realizó por medio de una carta fechada el 30 de septiembre de 1712 entregada por el secretario de estado don Ramón de Vilana Perlas, marqués de Rialp (en nombre de la emperatriz Isabel Cristina, gobernadora de los reinos y dominios de España en ese momento) al nuncio de Su Santidad, Jorge Spinola, arzobispo de Cesarea, que seguía en Barcelona:

«Ilustrísimo señor. Concluido con los enemigos el canje de los prisioneros de Estado y establecidos los actos de libertad al Prelado Obispo de Barcelona con los pasaportes consiguientes, me manda la Emperatriz mi señora a decir a V. S. Illma. que hallándose este Prelado con la nómina del Emperador mi Amo para Inquisidor General de sus dominios de España, se mira precisa la solicitud y expedición del Breve Apostólico en su persona, y persuadiendo la importancia de su brevedad el mismo estado de las cosas, por lo que se necesita el reparo de cualquier abuso introducido con la guerra y por lo que se interesa el religioso celo de Su Santidad en el restablecimiento de tan Santo Tribunal a la mayor exaltación de la fe, me ordena S: M. C. expresar a V. S. Ilma. que para el despacho de este Breve confía de su dirección y buenos oficios con Su Santidad el término más pronto, ni puede servir de embarazo alguno el Breve que se despachó últimamente en cabeza del Obispo de Vique, pues sabe V. S. Ilma. que este no ha tenido ejecución, y que se obtuvo por no gozar aquel Prelado de su plena libertad. Dios Guarde etc. Palacio, Septiembre 30 de 1712. El Marqués de Rialp»70.

En esta comunicación se menciona expresamente la existencia de un breve despachado por el papa para el mismo empleo en favor del obispo de Vic, «el breve que se despachó últimamente en cabeza del obispo de Vique». Es decir, a 30 de septiembre de 1712, fecha de esta carta, el rey Carlos había realizado el nombramiento de inquisidor general y había recibido la confirmación del mismo por el santo padre. Dicho nombramiento no se había puesto en ejecución una vez recibido en Barcelona; se había obtenido en defecto del solicitado para el cardenal Sala y siempre con la idea de que fuese este quien desempeñase el empleo de inquisidor general.

68 Duran i CanYameres, Fèlix: «Catalunya sota el govern dels reis absoluts de la casa de Borbó», en Revista Jurídica de Catalunya, 40 (1934), pp. 203-204.

69 Solís: «Política catalana de Carlos de Austria», pp. 239-240.

70 Archivio Vaticano, SS. Spagna, vol. 395, fols. 201-202, original, «Carta del secretario de estado del rey Carlos III al nuncio en Barcelona de Su Santidad Clemente XI solicitando la expedición del breve de inquisidor general en la persona del obispo de Barcelona. Barcelona, 30 septiembre 1712». Publ. AlBAREDA: «Contribució», apéndice LVI.

Hispania, LXV/2, núm. 220 (2005) 515-542 
Con fecha 22 de octubre del mismo año 1712, el secretario de estado pontificio enviaba al nuncio de Su Santidad en Barcelona el breve con el nombramiento del obispo de Barcelona como inquisidor general, por los dominios y reinos de España poseídos por el emperador, "per i dominii e regni di Spagna posseduti dall'Imperatore» ${ }^{71}$. De los tribunales de distrito existentes ${ }^{72}$ sólo estarían sujetos a su autoridad los de Barcelona, Mallorca y Cerdeña, bajo soberanía entonces del rey Carlos. Este nuevo breve se expedía, según especificaba el secretario de estado del santo padre, cardenal Fabricio Paulucci, con la salvaguardia de que el mismo no fuera publicado hasta que el obispo Sala hubiera reingresado en su diócesis, «essendo peró intenzione della Santità Sua che quello non si publichi se non dopo che el medesimo Prelato sara giunto al suo vescovato». El breve debía ser retenido por el nuncio hasta ese momento y entregado luego a la majestad de la emperatriz Isabel Cristina o al mismo obispo Benito Sala. El secretario de estado pontificio indicaba la conveniencia de recoger el breve anterior despachado para el mismo empleo de inquisidor general y remitirlo a Roma, porque no podía haber dos breves en dos personas diversas para el mismo cargo, "perche non habbiano a restare due Brevi in due persone diverse per l'istessa carica». Ese breve expedido en la persona del obispo de Vic no había tenido efecto, puesto que no había sido entregado ni publicado.

Con la misma fecha de 22 de octubre de 1712 se comunicó por el agente de S.M.C. en Roma al obispo Sala que tendría a su disposición en Barcelona el breve de inquisidor que por correo de ese día se enviaba al nuncio. Ya se habrían cumplido dos de los requisitos que exigía el romano pontífice antes de su entrega: la libertad efectiva de Sala y la retirada del breve de inquisidor general concedido anteriormente al obispo de Vic. Tan sólo faltaba el pago en mano de los derechos por la expedición del breve, que al parecer importaban algo más de setenta y cinco doblones ${ }^{73}$. El breve de inquisidor general en favor del obispo de Barcelona no llegó a entregarse, tal y como consta en carta de fecha 10 de junio de 1713 del secretario de estado pontificio al nuncio en Barcelona, ahora en Génova tras la evacuación de la capital del principado de Cataluña. El nuncio se llevó consigo el mencionado breve de inquisidor y ello incluso a pesar de que en el momento de abandonar Barcelona le fue demandada su entrega por parte del obispo don Benito Sala ${ }^{74}$. Sala había regresado a su diócesis el 10 de abril de 1713; y partió definitivamente de Barcelona el 3 de julio de ese

\footnotetext{
71 «Carta del secretario de estado de la Santa Sede al nuncio de Barcelona con el envío del breve de nombramiento de Inquisidor General en favor del obispo Sala (Roma, 22 octubre 1712)», en ALBAREDA: "Contribució", apéndice LIX .

72 Cfr. Contreras, Jaime, y DeDIEU, Jean Pierre: «Geografía de la Inquisición española: la formación de los distritos 1470-1820» en Hispania, 144 (1980), pp. 37-93.

73 GIRBAL: Biografía, p. 30.

74 ALBAREDA: «Contribució», apéndice LXXII.
} 
mismo año, acompañado del canónigo don Francisco Josa ${ }^{75}$, quien le asistiría en el exilio hasta su muerte ${ }^{76}$.

No es cuestión de extenderse aún más en esta ocasión en torno a la biografía de una persona tan conocida como el cardenal Sala. Únicamente se puede destacar la terrible persecución a la que fue sometido por el rey Felipe V. Sufrió destierro de su diócesis en Madrid y prisión, primero en Bayona y en Burdeos, y luego - gracias a la intercesión de Su Santidad- prisión algo más laxa en Aviñón, junto al patriarca de las Indias Portocarrero y al antiguo inquisidor general Mendoza. Su fidelidad a la Augustísima Casa fue patente en todo momento en que tuvo ocasión de demostrarlo, sin poder ser acusado - aunque se intentó - de haber favorecido o haber inclinado a los fieles de su diócesis hacia la causa del rey Carlos. Una vez confirmada, en consistorio de 30 de enero de 1713, la elevación del obispo de Barcelona al cardenalato, el rey Felipe, por decreto de 24 de marzo de 1713 , prohibió a sus ministros que lo reconocieran como cardenal, «no siendo justo ni de mi Real decoro dejar sin alguna manifestación de mi debido resentimiento un acto tan ofensivo y opuesto a mis incontrastables derechos de sangre, llamamiento y posesión». Así lo expresaba el 28 de agosto de 1713 al cardenal Acquaviva, previniéndole juntamente «que había mandado participar esta declaración al Rey Cristianísimo, mi abuelo, pidiéndole ordenase lo propio a sus cardenales y ministros en los países donde se hallasen, a fin de que todos viesen y reconociesen la unión y conformidad que hay entre las Dos Coronas» ${ }^{77}$. Este resentimiento de Felipe V llegó hasta el extremo de tratar de que se privase a Sala de las honras debidas a un cardenal en su fallecimiento. Muerto fray Benito el 1 de julio de $1715^{78}$, se alegó que no podía usarse del ceremonial acostumbrado, puesto que no había recibido el capelo directamente de manos del papa, por el delicado estado de salud del obispo desde su llegada a Roma. Clemente XI, informado de lo que sucedía, envió a casa del difunto el capelo de cardenal ${ }^{79}$.

\section{LA FORMACIÓN DEL CONSEJO DE LA INQUISICIÓN POR EL REY CARLOS}

Con el breve de inquisidor general concedido a favor de una persona de su nómina (aunque aún no hecho efectivo), la administración del rey Carlos consideró la necesidad de formar posteriormente el Consejo de la Suprema, responsable del gobierno del Santo Oficio junto al inquisidor, "que es la cabeza, y el que segun la mas segura opinion tiene el voto decisivo ${ }^{80}$. Se trataba de tener

\footnotetext{
75 GIRBAL: Biografia, pp. 31, 32 y 40 .

76 Cfr. AlCOBERRo, Agustí: L'exili austriacista (1713-1747), vol. I, Barcelona, 2002, p. 88.

77 ALBAREDA: «Contribució», pp. 125-127 y apéndice LXXIII.

78 GIRBAL: Biografía, p. 42.

79 ALBAREDA: «Contribució», p. 131.

80 Haus-, Hof- und Staatsarchiv (Viena), Spanien, Varia, karton 51, carpeta c, fols. 45r-48r.
} 
prevista una serie de personas para configurar el Consejo en el momento en el que se produjese la declaración de inquisidor general, "pues sin este preliminar no es dable que pueda haver proposicion, ni los nombramientos que pertenezen al Inquisidor» ${ }^{81}$. De ese modo, el 26 de julio de 1711, la secretaría de estado del rey Carlos elevaba una relación de ministros y oficiales que juzgaba «a proposito para los citados empleos» indicando de forma expresa el nombre de siete ministros y la designación también de secretario, de fiscal, de alguacil mayor y de contador general ${ }^{82}$. En cuanto se refiere a los consejeros, la planta seguía la que se encontraba en vigor en la práctica en el reinado de Carlos II ${ }^{83}$.

Aparte de otras varias consideraciones, la provisión de las plazas de consejero en el de la Inquisición debía recaer en personas con la formación y la experiencia necesarias para al servicio del Santo Oficio. A finales del siglo XVII lo regular era que los consejeros hubieran pertenecido anteriormente a alguno de los tribunales de distrito. Todos los ministros de la Suprema eran eclesiásticos. Los propuestos para el Consejo de la Inquisición del rey Carlos fueron don Martín de Viñuales, don Lorenzo Tomás y Costa, don Jorge Truyols, don Pedro de Castro, el doctor Ivo Casañas, don José Hualte y el maestro fray Domingo Pérez. Reunían en su conjunto, como se expone a continuación, condiciones más que suficientes para el desempeño de una plaza de inquisidor en el Consejo.

Don Martín de Viñuales, aragonés, catedrático de cánones en la universidad de Huesca ${ }^{84}$, era canciller de competencias del reino de Aragón ${ }^{85}$ y vicario general del arzobispado de Zaragoza cuando se le designó para la Junta Eclesiástica de Secuestros y Confiscaciones de Aragón, por decreto del rey Carlos de 23 de julio de $1706^{86}$. Fue elegido presidente de esta Junta de secuestros con fecha 27 de julio del mismo año 1706, "por no aber venido a concurrir en ella Dn Josef Panzano Abad de Montearagon ${ }^{87}$. Martín de Viñuales fue obispo electo de Huesca, presentado para dicha mitra por el rey Carlos el 5 de septiembre de $1707^{88}$; aun-

81 H.H.St.A., Spanien, Varia, k. 51, c, fol. 46r.

82 H.H.St.A., Spanien, Varia, k. 51, c, fols. 46v-47v.

83 LÓPEZ VELA, Roberto: «Estructuras administrativas del Santo Oficio», en Historia de la Inquisición en España y América, vol. II, Madrid, 1993, pp. 131-132. Respecto de la planta decretada en 1677, coincidente con la original, vid. MARTínez MilláN y SÁNCHEZ RIVILla: «El Consejo de Inquisición", pp. 72, 73, 87 y 105-106.

84 ARCO, Ricardo del: Memorias de la Universidad de Huesca, vol. I, Zaragoza, 1912, p. 139.

85 A.H.N., Estado, leg 281-1, Mercurio Veloz, particulares noticias publicadas en Zaragoza a 23 de julio de 1706, p. 4.

86 A.H.N., Consejos suprimidos, leg. 6.803, núm. 107, «Registro de las resoluciones y acuerdos de la Ilma. y Rl. Junta eclesiástica formada en el presente Reyno de Aragon por la Magestad Católica del Rey ntro. Sr. Carlos $3^{\circ}$ mediante su Real Despacho", copia 1 (notario Francisco Cayetano Nasarre), fols. 1r-1v. Cfr. Solís: «Las Juntas de Secuestros», pp. 433-434.

87 A.H.N., Consejos suprimidos, leg. 6.803, núm. 107, copia 2 (se trata de otra copia similar del registro citado en la nota anterior, esta de fecha 16 de diciembre de 1707 del notario Pedro Gerónimo Molinos), fol. 2r. Cfr. Solís: «Las Juntas de Secuestros», p. 459.

88 FeLIU: Anales, III, p. 595. 
que evidentemente no obtuvo la confirmación del papa. En 1711 era obispo electo de Albarracín por promoción del obispo de esa diócesis, fray Juan Navarro, para el arzobispado de Zaragoza, ambos prelados en la nómina del rey Carlos.

Don Lorenzo Tomás y Costa, catalán, canónigo de Vic, vicario general de ese obispado, fue nombrado por el rey Carlos para formar parte de la Junta Eclesiástica de Cataluña constituida el 18 de septiembre de 1705, «cerca de Sarriá»; recibió a continuación la merced de canciller de la audiencia de Cataluña ${ }^{89}$. En junio de 1706 el rey le concedió una gracia de capellán de honor y lo ennoblecióo ${ }^{90}$ don Lorenzo Tomás continuó en el exilio al servicio del rey Carlos, emperador de Alemania ${ }^{91}$.

Don Jorge Truyols, mallorquín, era inquisidor del tribunal de distrito de Mallorca ${ }^{92}$. Había sido nombrado con fecha 30 de mayo de 1700 fiscal de ese mismo tribunal de la Inquisición, aunque nunca llegó a servir este empleo al ser favorecido el 10 de septiembre de 1700 con un nombramiento de inquisidor ordinario del tribunal de la Inquisición de Corte ${ }^{93}$. Los Truyols eran austriacos notorios en Mallorca94. Este mismo Jorge Truyols había recibido con fecha 25 de julio de 1707 una cédula secreta del rey Carlos de merced de una plaza de consejero en el de Órdenes Militares ${ }^{95}$.

Don Pedro de Castro, castellano, "Consejero de Hazienda, y Inquisidor que fue de Sicilia», "del Habito de Santiago», pasó a Guadalajara a esperar al rey Carlos, tras haber dado Madrid la obediencia en julio de 1706. Figura entre «los particulares de los Reynos de la Corona de Castilla, y Navarra que dexaron sus casas, è haziendas, para seguir la Iusticia del Rey Nuestro Señor Carlos III. y vinieron à Barcelona» de quienes Feliu da escueta noticia en el tomo III de sus Anales ${ }^{96}$. El rey Carlos concedió a don Pedro de Castro el 2 de agosto de 1708 una plaza en el tribunal de la contaduría mayor del Consejo de Hacienda de Castilla ${ }^{97}$; el despacho de ese nombramiento lleva fecha de 4 de agosto del mismo año $1708^{98}$. Su pensión corría a cargo de la Junta de Secuestros de Mallorca99.

89 CASTELlví: Narraciones, I, pp: 533, 541-542, 598-599, 620 y 624.

90 Feliu: Anales, III, pp. 575 y 576.

91 Cfr. Solís: «Las Juntas de Secuestros», pp. 430, 431 y 458.

92 A.H.N., Estado, leg. 8.688, «Nombramientos y cargos concedidos por el archiduque. Por orden alfabético L-X».

93 Domínguez Salgado, María del Pilar: «Inquisidores y Fiscales de la Inquisición de Corte (1580-1700)", en Revista de la Inquisición, 4 (1995), p. 246.

94 Duran i CANYAmeres, Fèlix: «El Decreto de Nueva Planta de la Audiencia de Mallorca», Boletín de la Sociedad Arqueológica Luliana, 28 (1941), p. 191.

95 A.H.N., Estado, leg. 8.688, «Nombramientos y cargos concedidos por el archiduque. Por orden alfabético L-X».

96 FELIU: Anales, III, pp. 582 y 632.

97 FeliU: Anales, III, p. 609.

98 A.H.N., Estado, leg. 8.695, «1707-1711. Certificados del marqués de Erendazu, de concesiones reales de cargos».

99 A.H.N., Estado, libro 994, «Tomo 3 de los negocios despachados de las Islas que contiene algunos decretos de S.M. consultas del Consejo de Aragón e informes de los virreyes de Cerdeña y Mallorca, memoriales despachados y otros papeles", fol. $1 \mathrm{r}$.

Hispania, LXV/2, núm. 220 (2005) 515-542 
El doctor Ivo Casañas, catalán, era canónigo de Vic ${ }^{100}$. Con fecha de 26 de noviembre de 1715 las autoridades borbónicas examinaban el memorial presentado por el sacristán mayor y canónigo de Vic don Ivo Casañas suplicando que no se le impidiera continuar en el servicio de la dignidad de la que se beneficiaba ${ }^{101}$; Casañas, por lo tanto, quizá permaneció en España una vez acatada la soberanía del rey Felipe V.

Don José Hualte, nacido en Vidángoz, en Navarra ${ }^{102}$, debía estar sin empleo en 1711, cuando se le incluye en esta nómina de posibles consejeros de la Inquisición, si bien el rey Carlos ya le había expedido una cédula secreta de merced de plaza en el Consejo y Cámara de Castilla «aunque por ahora, y hasta que yo mande otra cosa, no aya de entrar en el exercicio de ella»103. Hualte, licenciado por la universidad de Zaragoza, había sido inquisidor en Cerdeña ${ }^{104}$, en Mallorca (donde consta en 1693) ${ }^{105}$, en Barcelona en $1702^{106}$, promovido al Consejo de Navarra con fecha 19 de mayo de $1705^{107}$ y al de Indias por cédula de 27 de septiembre de $1706^{108}$, último cargo que desempeñó antes de incorporarse al partido austriaco ${ }^{109}$.

Fray Domingo Pérez, en 1673, con tan sólo doce años de edad, «había llamado a las puertas del convento de Santo Tomás de Madrid pidiendo el hábito blanco de los hijos de Santo Domingo». Fue catedrático en la universidad de Alcalá ${ }^{110}$, calificador del Santo Oficio nombrado el 13 de septiembre de $1700^{111}$ y maestro de su Religión en 1703. De Alcalá pasó siguiendo al rey Carlos a la corte de Barcelona, donde residió hasta el 7 de julio de 1711. Clemente XI, a solicitud del rey, lo nombró inquisidor en el territorio de Fermo (en las Marcas)

100 Albareda I Salvadó, Joaquim: «La guerra de successió a Osona: 'vigatans' i 'botiflers'», en Primer Congrés d'Història Moderna de Catalunya, vol. 2, Barcelona, 1984, p. 258.

101 A.H.N., Consejos suprimidos, leg. 6.811 A, núm. 155, «Parecer del Consejo sobre el memorial de don Ivo Casañas». Cfr. SARrablo AGÜARELES, Eugenio: Catálogo de consultas del Consejo de Aragón, Madrid, 1975, p. 178.

102 Sesé Alegre, José María: El Consejo Real de Navarra en el siglo XVIII, Pamplona, 1994, p. 285.

103 A.H.N., Estado, leg. 8.687, «Nombramientos y cargos concedidos por el archiduque. Por orden alfabético A-K».

104 SESÉ: El Consejo Real de Navarra, p. 285.

105 MUNTANer I MARIANO, Lleonard: «Los grandes ciclos de actividad de la Inquisición española en Mallorca (1488-1691)», en Perfiles jurídicos, p. 755.

106 VOLTES BOU, Pedro: Barcelona durante el gobierno del archiduque Carlos de Austria (17051714), vol. I, Barcelona, 1963, p. 119.

107 SESÉ: El Consejo Real de Navarra, p. 285.

${ }_{108}$ BERNARD, Gildas: Le Secrétariat d'État et le Conseil espagnol des Indes (1700-1808), GinebraParís, 1972, p. 214.

109 Sobre Hualte y su vinculación a otros órganos de la administración española del archiduque vid. Solís, José: «Notas para el estudio del Consejo de Indias del archiduque Carlos de Austria», en VII Congreso Internacional de Historia de América, vol. I, Zaragoza, 1998, pp. 695, 700 y 707.

110 Pérez Goyena, Antonio: «Teólogos antifranceses en la Guerra de Sucesión», en Razón y Fe, 91 (1930), pp. 503-504.

111 MARTíNeZ MilláN y SÁNCHeZ Rivilla: «El Consejo de Inquisición», p. 188. 
y, en 1721, secretario de la Congregación del Índice. Se conocen al menos dos obras teológicas del padre Domingo Pérez, ambas impresas después de su fallecimiento. También es póstuma la publicación de sus sermones, en Madrid, en 1745 , en dos tomos en folio ${ }^{112}$. Fray Domingo Pérez habría sido incluido entre los posibles integrantes del Consejo de la Inquisición del rey Carlos para desempeñar la plaza del Consejo adscrita a la orden de Santo Domingo.

Puede recordarse, en relación con esta plaza de la orden de Predicadores, que la misma constituía una prerrogativa de dicho instituto religioso independiente del desempeño del oficio de confesor real ${ }^{113}$. El confesor no tenía plaza en el Consejo de la Inquisición por razón de su cargo pero formaba parte del mismo con frecuencia dado que solía recaer en él cuando era dominico (lo cual fue lo corriente durante el siglo XVII) la plaza reservada a esta orden en el Consejo de la Suprema. En 1711 el confesor del rey Carlos era el padre jesuita Veit Tönnemann ${ }^{114}$.

En cuanto a los restantes empleos antes mencionados, se señala también el nombramiento de secretario de S.M., para cuyo desempeño se destaca, entre otros, a don Manuel de Legazpi, "oficial que era de Estado»"${ }^{115}$. Manuel Tomás de Legazpi Echeverría, caballero de la orden de Calatrava desde $1691^{116}$, oficial de número de la mencionada secretaría por nombramiento de Carlos II, obtuvo el despacho del título de oficial mayor de la secretaría de estado de las negociaciones de Italia y España el 21 de septiembre de 1711, siendo entonces secretario de dichas negociaciones don Juan Antonio Romeo y Anderaz, marqués de Erenda$\mathrm{zu}^{117}$. El secretario de S.M. en el Consejo de la Inquisición se nombraba «sin proposicion del Inquisidor ${ }^{118}$. Era responsable de despachar con el rey los asuntos relativos a este Consejo, y precedía protocolariamente al fiscal de la Suprema ${ }^{119}$.

Por lo que se refiere al fiscal del Consejo del Santo Oficio, este empleo era designado libremente por el inquisidor general, no obstante la formalidad de su comunicación al monarca, «un fiscal que nombra el Inquisidor, dando quen-

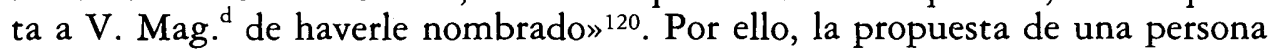
para este cargo no debería tener apenas trascendencia si no contaba con la plena conformidad del inquisidor. La secretaría del rey Carlos, en cualquier caso, consideraba en 1711 que se podría tener en cuenta para fiscal a don Marcos

\footnotetext{
112 PÉREZ GoYena: «Teólogos antifranceses», pp. 504-507.

113 MARTíneZ MilláN, José: «Los miembros del Consejo de Inquisición durante el siglo XVII», en Hispania Sacra, 37 (1985), p. 413.

114 Cfr. Batllori, Miquel: La Il-lustració. Obra completa, vol. IX, Valencia, 1997, p. 167, nota 1.

115 H.H.St.A., Spanien, Varia, k. 51, c, fol. 47r.

116 VIGNAU, Vicente, y UHAGÓN, Francisco R. de: Índice de pruebas de los Caballeros que ban vestido el Hábito de Calatrava, Alcántara y Montesa desde el siglo XVI hasta la fecha, Madrid, 1903, p. 47.

117 A.H.N., Estado, leg. 8.688, «Nombramientos y cargos concedidos por el archiduque. Por orden alfabético L-X».

118 H.H.St.A., Spanien, Varia, k. 51, c, fol. 45v.

119 AldEA VAQUERO, Quintín: «Los miembros de todos los Consejos de España en la década de 1630 a 1640», en Anuario de Historia del Derecho Español, 50 (1980), p. 196.

120 H.H.St.A., Spanien, Varia, k. 51, c, fol. $45 \mathrm{v}$.
} 
Marañón, un antiguo relator (nombrado el 18 de julio de $1703^{121}$ ) del Consejo de la Suprema. Don Marcos Marañón y Lara era bachiller por la universidad de Alcalá. En 1699, a los veintinueve años de edad, obtuvo una plaza de oidor en la audiencia de Santo Domingo, nombramiento que no aceptót ${ }^{122}$.

Finalmente, se habrían considerado algunos otros nombramientos para el Consejo de la Inquisición, en concreto el de contador general (puesto para el que se proponía a Prudencio Gregorio de la Fuente) y el de alguacil mayor (que podría servir don Jerónimo Antonio de Magán y Morales, natural de Pastrana, caballero de la orden de Santiago ${ }^{123}$ ). También se efectuó la concesión de una de las tres porterías del Consejo, «con la facultad (...) para sustituir a su arbitrio persona que la sirva", en beneficio de doña María Luisa de Castañeda y Ordaz, merced fechada en Barcelona el 22 de septiembre de $1711^{124}$. Quedaba así completa la nómina necesaria para el funcionamiento básico del organismo. Su constitución, sin embargo, al igual que la designación de los restantes empleos, seguía dependiendo de que previamente se hubiera efectuado la provisión del cargo de inquisidor general:

«Y los demas empleos sera facil llenarlos luego que este formado el Consexo no deviendo omitir que respecto de haver Su Santidad convenido en consequencia

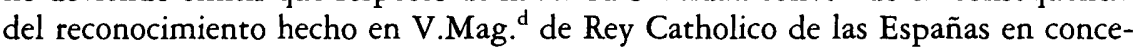
der los Breves de Inquisidor General con todas las circunstancias, pareze que la autoridad, y decoro Real acompañados de la verdadera razon de Estado piden, que este tribunal se forme sin faltar circunstancia, ni formalidad de este Consexo de suerte que no se advierta discrepancia alguna en el Consexo de V. Mag. ${ }^{\text {d }}$ de la formacion que siempre ha tenido en España»125.

\section{El NOMBRAMIENTO DE INQUISIDOR GENERAL POR CLEMENTE XI}

En la Inquisición española, como se sabe, la máxima autoridad era ejercida por el inquisidor general, que tenía competencia exclusiva en los asuntos de gobierno y extendía sus atribuciones a la designación y el control de la mayoría del personal vinculado al Santo Oficio. En principio, todos los nombramientos de inquisidores y oficiales dependían del inquisidor general. En cuanto a la elección de los ministros del Consejo, también correspondía al inquisidor gene-

\footnotetext{
121 Martínez MilláN y SÁNCHeZ RIVILla: «El Consejo de Inquisición», p. 163.

122 BURKHOlder, Mark A. y ChANDler, Dewitt S.: De la impotencia a la autoridad. La Corona española y las Audiencias en América. 1687-1808, México, 1984, pp. 242-243 y 434-435.

123 VIGNAU, Vicente, y UHAGÓN, Francisco R. de: Índice de pruebas de los caballeros que ban vestido el bábito de Santiago desde el año 1501 basta la fecha, Madrid, 1901, p. 204.

${ }^{124}$ A.H.N., Estado, leg. 8.687, «Nombramientos y cargos concedidos por el archiduque. Por orden alfabético A-K».

${ }^{125}$ H.H.St.A., Spanien, Varia, k. 51, c, fols. 47v-48r.
} 
ral la presentación de una terna al rey para cubrir cada vacante ${ }^{126}$. Evidentemente, toda esta práctica (en caso de ser mantenida ${ }^{127}$ ) hacía que el cargo de inquisidor general fuera imprescindible para el adecuado funcionamiento del Santo Oficio 128 . En este sentido, y desde el momento en el que se comprobó la imposibilidad de mantener la comunicación con los supremos órganos de la administración inquisitorial, el rey Carlos nombró inquisidor general al obispo de Barcelona, con la finalidad de restablecer el ordinario funcionamiento de la Inquisición y como expresión, además, de sus atribuciones en cuanto rey de España. Esta facultad que tenía para nombrar inquisidor general le había sido reconocida de manera explícita por el sumo pontífice, sin perjuicio de los mismos derechos que tenía Felipe V.

Después de la muerte, en 1710, del inquisidor general Ibáñez de la Riva Herrera, la Santa Sede concedió breves de nombramiento de inquisidor general tanto a la persona propuesta por Carlos III (el obispo de Vic Manuel de Senjust, aunque sin efectuarse en espera del solicitado para el cardenal Sala) como en favor asimismo del cardenal Iudice (cuyo placet no habría podido negar Su Santidad), presentado por Felipe $\mathrm{V}$ en lugar del obispo de Cuenca Miguel del Olmo. Se produjo así una situación — que, por otro lado, tampoco debía ser especialmente compleja ni era nueva por completo- en la que la Inquisición de una parte de la corona de Aragón estaría regida por un inquisidor general propio, configurando una Inquisición separada de la de Castilla. Y de hecho, tanto para Cerdeña como luego para Sicilia cuando pasó a su soberanía, el rey Carlos mantuvo la estructura inquisitorial del periodo español ${ }^{129}$, existiendo en consecuencia un inquisidor general en la corte de Viena.

Según se ha expuesto, el breve de nombramiento de inquisidor general en favor del cardenal Sala fue remitido al nuncio del papa en Barcelona el 22 de octubre de 1712, en cuanto se produjo la liberación del religioso hasta entonces prisionero de Felipe V. El breve de nombramiento del cardenal Iudice fue expedido el 2 de junio de 1711 y tomó posesión de su cargo el 7 de marzo de $1712^{130}$.

Francisco Iudice, consejero de estado en 1699, virrey de Sicilia de 1702 a $1705^{131}$, alcanzó como inquisidor general un poder político considerable en la corte del rey Felipe V, con el apoyo de la Santa Sede y defendiendo los intereses

126 BARRIOS, Feliciano: «Las competencias privativas del Inquisidor General en la normativa regia de los siglos XVI y XVII. Una aproximación al tema», en Revista de la Inquisición, 1 (1991), pp. 130,132 y 134

${ }_{127}$ Cfr. LeÓn SANZ, Virginia: Entre Austrias y Borbones. El Archiduque Carlos y la Monarquía de España (1700-1714), Madrid, 1993, p. 73.

128 ESCUDERO, José Antonio: «Inquisidor General y Consejo de la Suprema: dudas sobre competencias en nombramientos», en Perfiles jurídicos, pp. 532-535.

129 Cfr. CANOSA, Romano: Storia dell'Inquisizione spagnola in Italia, Roma, 2002, pp. 133-134, $138-139$ y 233.

130 MARTíneZ Millán y SÁNCHEZ RIVILla: «El Consejo de Inquisición», p. 113.

131 Barrios, Feliciano: El Consejo de Estado de la Monarquía española, 1521-1812, Madrid, 1984, p. 407.

Hispania, LXV/2, núm. 220 (2005) 515-542 
de esta. Camino de Madrid tras su nombramiento, prometió en Aviñón al nuncio de Su Santidad (todavía no admitido por Felipe V) que interpondría su valimiento y prestigio con el rey para intentar un acuerdo de este con el pontífi$c^{132}$. En España, Francisco Iudice se revelaría como uno de los más firmes defensores de las inmunidades eclesiásticas frente a los propósitos de su limitación por parte del poder real. Esta fue una de las causas por las cuales sería destituido y expulsado de España. En 1718 el cardenal Iudice entró al servicio del emperador Carlos VI como su embajador en Roma ${ }^{133}$.

La inquisición dependiente del emperador conservó la misma estructura que tenía hasta entonces y también la figura característica del inquisidor general. Una vez fallecido el cardenal Sala, el pontífice, con fecha 28 de agosto de 1715 , concedió el breve de inquisidor general a propuesta del emperador Carlos VI en favor del padre maestro don fray Juan Navarro, obispo de Albarracín $^{134}$. El breve, al igual que los anteriores despachados a instancias de este monarca, se expedía por los dominios que poseía con las facultades de Rey Católico y aquellos que en el mismo concepto pudiera poseer en el futuro.

Fray Juan Navarro Gilaberte O. de M. era obispo de Albarracín presentado por Felipe V el 1 de marzo de $1704^{135}$, electo arzobispo de Zaragoza por el rey Carlos para suceder en 1710 a Ibánez de la Riva Herrera, juez del breve por nombramiento también del rey Carlos ${ }^{136}$ quien, como se ha dicho, lo designó en 1715 para desempeñar el cargo de inquisidor general, con autoridad en Cerdeña, primero, y después en Sicilia ${ }^{137}$. Como tal celebró en Palermo en 1724 un auto general de fe, cuya relación impresa en siete pliegos en folio dedicó a Su Majestad ${ }^{138}$. Fray Juan Navarro, aragonés natural de Calatayud, bachiller en Artes por la universidad de Huesca, había sido general de la Merced, confirmado por Inocencio XII el 14 de junio de $1698^{139}$. Durante su gobierno obtuvo la grandeza de España para su orden, "gracia que abia mucho tiempo que solicitaba la Religion» ${ }^{140}$, quedando así equiparados sus generales a los de Santo Domingo, San Francisco, Capuchinos y el Carmen ${ }^{141}$; la función de cubrirse se celebró el día 2 de abril de $1699^{142}$.

\footnotetext{
132 FernáNDeZ AlONSO: «Un período de las relaciones entre Felipe V y la Santa Sede», p. 65.

${ }_{133}$ MaRqués de SAN Felipe: Comentarios de la Guerra de España e Historia de su Rey Felipe V, el Animoso (Génova, 1725), cito la edición de la B.A.E., Madrid, 1957, pp. 269-270 y 301.

${ }^{134}$ CASTELlVí: Narraciones, IV, pp. 468-469.

135 PÉREZ GOYENA: «Teólogos antifranceses», p. 339.

136 A.H.N., Estado, libro 1.002, «Registro de las consultas del Consejo de Estado y Junta de Estado y Guerra, año de 1711 », segunda foliación, fols. 69r-69v.

137 CASTELlví: Narraciones, IV, pp. 469 y 713.

138[LATASSA, Félix de]: Bibliotecas antigua y nueva de escritores aragoneses de Latassa anotadas y refundidas en forma de diccionario bibliográfico-biográfico por don Miguel Gómez Uriel, vol. II, Zaragoza, 1885, p. 405.

139 PÉrez GOYENA: "Teólogos antifranceses», 338.

140 Biblioteca Universitaria de Zaragoza, ms. 293, «Diario de los sucesos políticos de la Monarquía desde el año 1693 al de $1704 »$, fol. 148v.

141 B.U.Z., ms. 293, fol. 18 r.

142 B.U.Z., ms. 293, fol. $148 \mathrm{v}$.
} 